\title{
風および潮流により生じる矩形橋脚への漂流船の 衝突確率計算手法に関する研究
}

久保雅義*・榊原繁樹* ・長谷川芳已**・長岡忠男*

\section{A Study on Calculation Method of Probability of Drifting-ship Collision to a Rectangular Pier due to Wind and Tides}

\author{
Masayoshi KUBO, Shigeki SAKAKIBARA, \\ Yoshimi HASEGAWA and Tadao NAGAOKA
}

\begin{abstract}
In a design stage of large bridge over an important sea rout, many investigations such as observations and/or predictions of the sea traffic volume and researches on an effective support system for sailing have been considered. In the study on ship collision to piers, some considerations, namely a selection of target ship dimensions, the collision patterns, calculations of the collision energy and so on have been done. However, few researches have been carried out on the probability of drifting-ship collision to the pier on each parts of it. In practice, some large fenders as the shock absorbers have been installed on the four sides and corners around the pier, respectively. It is important and difficult to arrange the shock absorbers around the piers, safely and effectively.

In this paper, a study on calculation method of probability of drifting-ship collision to a rectangular pier due to wind and tides were carried out considering positions of the pier. And a case study for a Japanese famous large bridge was demonstrated.
\end{abstract}

\section{1，緒言}

現在瀬戸内海には、本州と四国を結ぶ 3 本の橋が 建設されている。建設に際し、船舶交通量の動態調 查・予測、適切な航行援助システムの構築など様及 な観点から検討が行われている。橋脚への船舶の衝 突に関する検討において、従来、対象船舶の選定、 衝突の形態挹よび衝突エネルギーの算出ならびに適 切な緩衝工の選定等の検討が行われており(1)、最近 では船舶の衝突シナリオを作成して定性的および定 量的な衝突の評価が行われるに至っている(2)(3)。ま た橋脚への衝突を、操船不能確率と橋脚への水平お よび鉛直・上部構造物への幾何学的衝突確率の積と して算出する計算手法が提案されている(4)。ただし 当該計算手法は、航路航行船が七ューマン・エラー などの操船ミスにより、ある進路を持って橋㑢に衝
突する場合を想定しており、船舶が機関および舵故 障等により自力航行できなくなり、風㧍よび潮流に より漂流して橋脚に衝突する状況は考えていない。 実際の事故事例を調べると、上述の漂流事故確率が かなり高い割合となる場合がある(5)。また橋脚の形 状や各部位への衝突確率まで計算した事例は少な く、実際、矩形形状をした橋脚の辺およびコーナ部 分（頂点）につき個別に緩衝工を設置して橋脚の損 傷軽減をはかる場合がある。

そこで本研究では、風および潮流により生じる矩 形橋脚一の漂流船の衝突確率計算手法を提案すると 共に、当該計算手法の南北備讃瀬戸大橋への適用事 例を紹介する。

* 正会員 神戸商船大学（厂658-0022 神戸市東灘区深江南町5-1-1）

** 非会員 本州四国連絡橋公団（一700-0031 岡山市富町2-19-12） 


\section{2. 矩形橋脚への漂流船の衝突確率計算手法}

\section{1 風による衝突確率}

\subsection{1 計算手順}

機関および舵故障等した船舶が、風により漂流し て矩形橋脚へ衝突する確率の計算手順を図 1 に示 す。基本的には船舶が海域のある場所において漂流 事故を発生し、風向きに沿って漂流して橋脚に衝突 する場合を考之る。

(1) 船舶の海域存在確率 $\mathrm{P}_{\mathrm{m}}(\mathrm{d}, \phi)$

まず船舶通航実態調查等により航跡図を描き、調 查期間内に打ける海域通航船の存在隻数を図 2 に示 すような各橋脚 $\mathrm{m}$ を心とする方位 $(\phi=\phi(\mathrm{m}))$ お

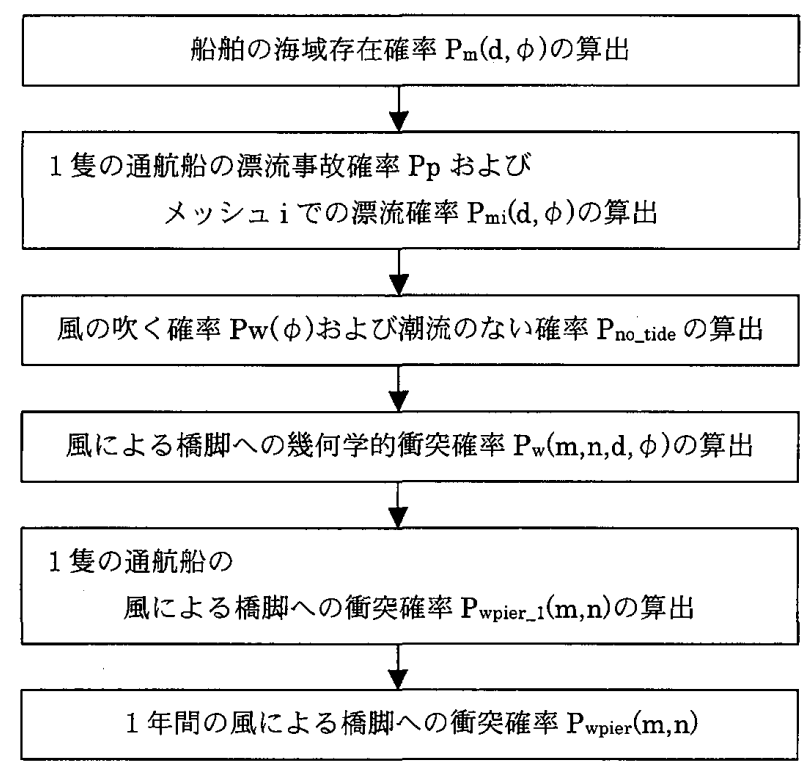

図 1 風による衝突確率の計算手順

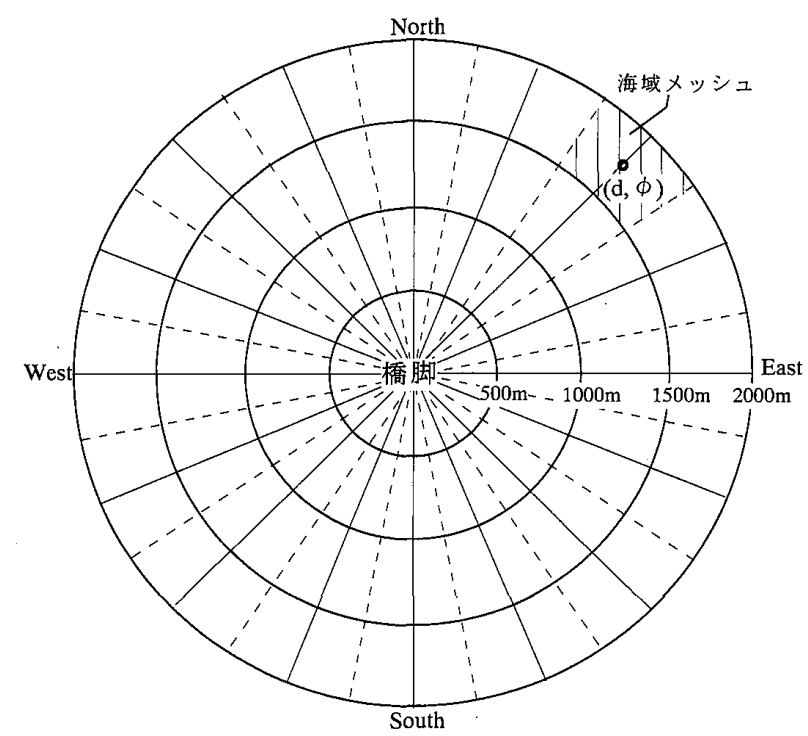

図 2 船舶の海域存在隻数算出のための 海域メッシュ（風による衝突）
よび距離 $(\mathrm{d}=\mathrm{d}(\mathrm{m}))$ で仕切られる局形メッシュ $\mathrm{i}$ $(\mathrm{i}=\mathrm{i}(\mathrm{m}))$ 内に存在する隻数を累計し、式(1)のよj に海域存在確率 $\mathrm{P}_{\mathrm{m}}(\mathrm{d}, \phi)$ を求好る

$$
P_{m}(d, \phi)=\frac{N_{i}}{N_{T}}, \quad N_{T}=\sum_{i=1}^{N D} N_{i}
$$

ここに、 $\mathrm{P}_{\mathrm{m}}(\mathrm{d}, \phi)$ はメッシュiにおける船船の海域存 在確率、 $\mathrm{N}_{\mathrm{i}}$ は船舶通航実態調查期間内に橋脚 $\mathrm{m}$ に対 するメッシュiに存在した船舶の累計隻数、 $\mathrm{N}_{\mathrm{T}}$ は対 象海域の存在隻数の総数、NDは海域の分割個数で ある。

(2) 漂流事故確率 $\mathrm{P}_{\mathrm{p}}$ およびメッシュiでの漂流確 率 $\mathrm{P}_{\mathrm{mi}}(\mathrm{d}, \phi)$

次に通航船の 1 隻が、海域航行中に漂流する確率 $\mathrm{P}_{\mathbf{p}}$ を設定する。これは船舶通航実態調查期間内の総 航行隻数と海難審判庁裁決録などから抽出した過去 に発生した漂流事故件数から式(2)のように算出す る。

$$
P_{p}=\frac{N_{a}}{N_{s}}
$$

ここに、 $\mathrm{P}_{\mathrm{p}}$ は 1 隻の通航船が海域航行中に漂流する 確率、 $\mathrm{Na}$ は所定の期間内に過去に発生した漂流事故 件数、Nsは船舶通航実態調查期間内の総航行隻数で あるが当該漂流事故抽出の期間に合せて適宜外挿す る場合がある。

以上より、1 隻の通航船が海域航行中にメッシュ $\mathrm{i}$ 位置から漂流して橋脚 $\mathrm{m}$ に衝突する確率 $\mathrm{P}_{\mathrm{m} 1}(\mathrm{~d}$, ф)は以下のようになる。

$$
P_{m i}(d, \phi)=P_{p} \times P_{m}(d, \phi)
$$

（3）風の吹く確率 $\mathrm{P}_{\mathrm{w}}(\phi)$ および潮流のない確率 $P_{\text {no tide }}$

一方風の吹く確率 $\mathrm{P}_{\mathrm{w}}(\phi)$ に関しては、当該海域に おける過去の風速および風向観測デー夕を統計処理 して、所定の風速以上の風の吹く確率を風向き $(\phi)$ ごとに求める。またここでは風のみにより船舶が漂 流する場合を考えているため、海域に潮流のない場 合の確率 $\mathrm{P}_{\text {no_tide }}$ を合せて設定する。

（4） 1 隻の通航船が風により橋脚へ衝突する確率 $\mathrm{P}_{\text {wpier } 11}(\mathrm{~m}, \mathrm{n})$

以上より、1隻の通航船が海域航行中に漂流して 橋脚 $\mathrm{m} の$ 辺または頂点 $\mathrm{n}$ 一衝突する確率 $\mathrm{P}_{\mathrm{wpie} \_}(\mathrm{m}$, n)は式(4)のように算出される。

$$
\begin{aligned}
P_{\text {wpier_ } 1}(m, n)= & \sum_{d} \sum_{\phi} P_{m i}(d, \phi) \times P_{w}(m, n, d, \phi) \\
& \times P_{w}(\phi) \times P_{n o_{-} \text {tide }}
\end{aligned}
$$

ここに、 $\mathrm{P}_{\mathrm{w}}(\mathrm{m}, \mathrm{n}, \mathrm{d}, \phi)$ は風による漂流船の橋脚 
$\mathrm{m}$ の辺または頂点 $\mathrm{n} へ$ へ幾何学的衝突確率である。

（5） 1 年間の風による橋脚への衝突確率 $\mathrm{P}_{\text {wpier }}$ $(\mathrm{m}, \mathrm{n})$

式(4)で求めた 1 隻の通航船が風により橋脚へ衝突 する確率 $\mathrm{P}_{\text {wpier_ } 1}(\mathrm{~m}, \mathrm{n})$ を用いて、 1 年間に橋脚 $\mathrm{m} の$ 辺または頂点 $\mathrm{n}$ 一衝实する確率 $\mathrm{P}_{\text {wpier }}(\mathrm{m}, \mathrm{n})$ は、式 (5)のように算定されることになる。

$$
P_{\text {wpier }}(m, n)=P_{\text {wpier_l }}(m, n) \times N_{s_{-} \text {year }}
$$

ここに、 $\mathrm{N}_{\text {s_year }}$ は 1 年間に海域を航行する総隻数で ある。

2.1 .2 風による橋脚への幾何学的衝突確率の計 算 $\left(\mathrm{P}_{\mathrm{w}}(\mathrm{m}, \mathrm{n}, \mathrm{d}, \phi)\right)$

風による橋脚 $\mathrm{m}$ の辺または頂点 $\mathrm{n}$ への漂流船の 幾何学的衝突確率 $\left(\mathrm{P}_{\mathrm{w}}(\mathrm{m}, \mathrm{n}, \mathrm{d}, \phi)\right)$ は次のよj に求める。

図 3 に示すように海域の任意のメッシュ內内に存 在する船舶はメッシュの中心位置に代表させる。そ して漂流船は風向きに船首尾線を直角にして漂流 し、橋脚 $\mathrm{m}$ に衝突する場合を考之る。一方橋脚 $\mathrm{m}$ の 各部位はP1からP8の 8 䇢所に分類し、P1、P3、P5、 $\mathrm{P} 7$ が橋脚の辺に、P2、P4、P6、P8がコー十部(頂点) とする。このときメッシュの方位分割幅を $\theta_{0}$ 、漂流船 が橋脚 $\mathrm{m}$ のP1、P2およびP3をみる角度をそれぞれ $\theta_{1}, 2 \theta_{2}$ おび $\theta_{3}$ とるとき、各部位の幾何学的衝突 確率を以下のように定義する。

$$
P_{w}(m, 1, d, \phi)=\frac{\theta_{1}}{\theta_{0}}, P_{w}(m, 2, d, \phi)=\frac{2 \theta_{2}}{\theta_{0}},
$$

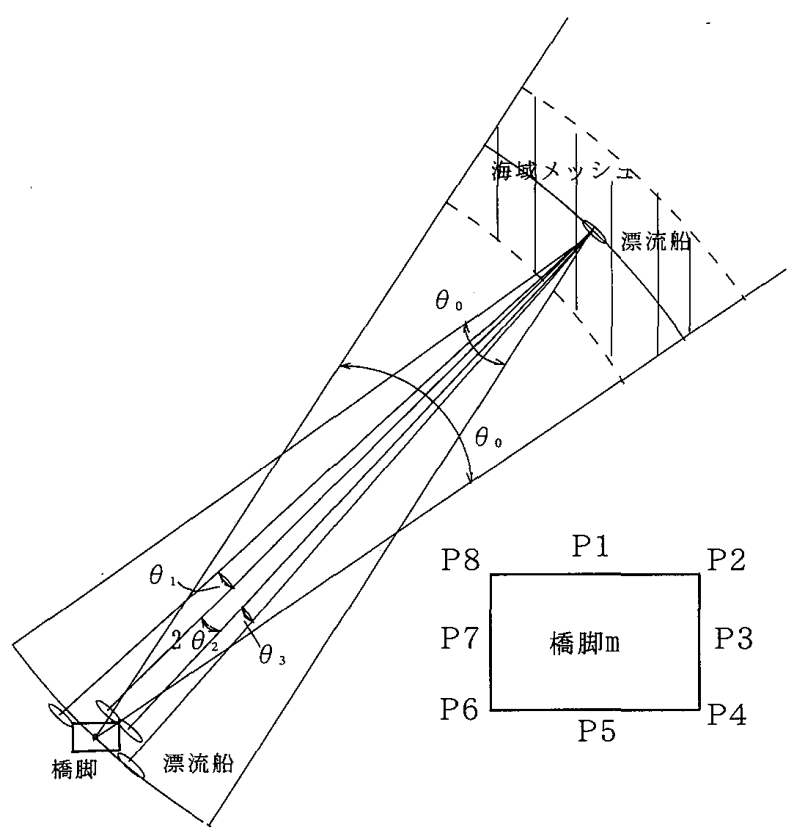

図 3 方位角と漂流船が橋脚をみる衝突角度 （風による衝突）

$$
P_{w}(m, 3, d, \phi)=\frac{\theta_{3}}{\theta_{0}}
$$

ここに、漂流船が橋脚 $\mathrm{m}$ の部位をみる角度 $\theta_{1} 、 2 \theta_{2}$ および $\theta_{3}$ は風向き、海域メッシュiと橋脚 $\mathrm{m}$ までの 距離と方位、漂流船舶の全長 (船長) および橋脚の 形状により次のように幾何学的に算出することがで きる。困 4 に橋脚と漂流船の位置関係の詳細困を示

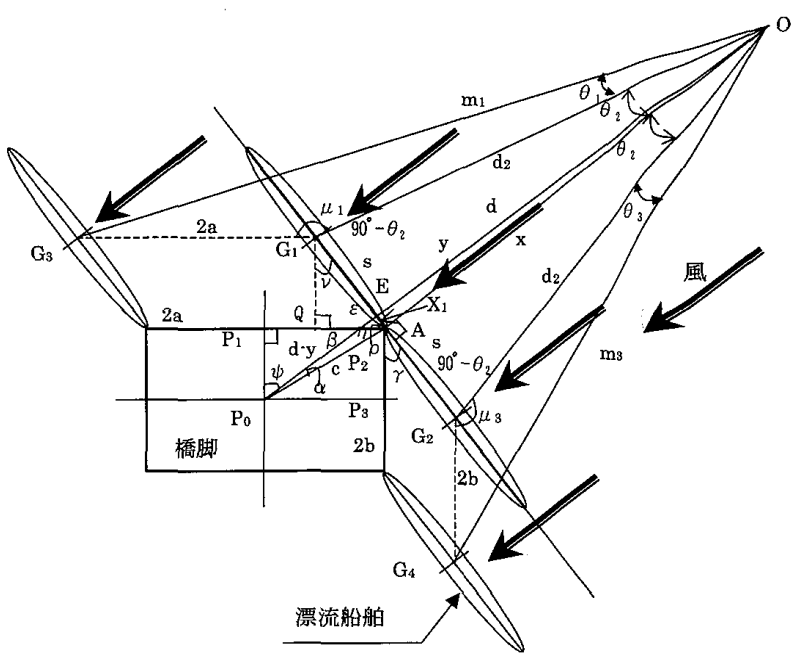

図 4 風による漂流船と橋脚との位置関係 (風による幾何学的衝突確率)

す。

（1）方位角 $\theta_{2}$ の算出

図 4 の点Oにおいて、船舶が漂流事故を発生した 場合を考える。 $\triangle O A G_{1}$ において、次式の関係式を得 る。

$\tan \theta_{2}=\frac{s}{x}, \quad d_{2}^{2}=x^{2}+s^{2}$

ここに、 $\mathrm{s}=\mathrm{L} / 2\left(\mathrm{~L} ：\right.$ 船長) である。また $\triangle \mathrm{OP}_{0} \mathrm{~A} に お ~$ いて、次式の関係式を得る。

$$
x^{2}=d^{2}+c^{2}-2 d c \cos \alpha
$$

ここに、 $c^{2}=a^{2}+b^{2}$ ( $\mathrm{a}$ ：橋脚半幅、 $\mathrm{b}$ ：橋脚半高さ)

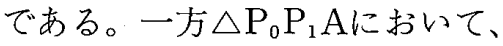

$$
\begin{aligned}
& (\varphi-\alpha)+\beta=90^{\circ} \text { より、 } \\
& \varphi=\alpha+90^{\circ}-\beta
\end{aligned}
$$

をとる。ここに される与值である。式 (7-3) で $\varphi$ は次式にて求めら れる。

$$
\varphi=\operatorname{Tan}^{-1} \frac{a}{b}
$$

したがって式 (7-3)、(7-4)より $\alpha$ は次式にて求めら れ、式 (7-1)、(7-2) より $\theta_{2}$ が得られる。 
$\alpha=\varphi+\beta-90^{\circ}$

(2) 方位角 $\theta_{1}$ の算出

図 4 の $\triangle \mathrm{OAE}$ にいて、次式の関係式を得る。

$X_{1}^{2}=y^{2}-x^{2}$

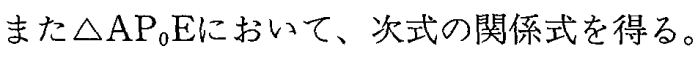

$X_{1}^{2}=c^{2}+(d-y)^{2}-2 c(d-y) \cos \alpha$

式（7-6）、（7-7）を整理すると、次式を得る。

$y=\frac{x^{2}+c^{2}+d^{2}-2 c d \cos \alpha}{2(d-c \cos \alpha)}$

したがって $y$ が得られることになり、式 (7-6)より

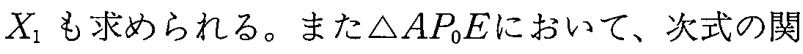
係式を得る。

$$
\begin{aligned}
& \frac{X_{1}}{\sin \alpha}=\frac{d-y}{\sin \rho}\llcorner\eta 、 \\
& \rho=\operatorname{Sin}^{-1}\left(\frac{d-y}{X_{1}} \sin \alpha\right)
\end{aligned}
$$

ここに、 $\rho=\eta+\varepsilon$ であり、 $\eta=\operatorname{Tan}^{-1} \frac{b}{a}$ で与えられ る $(\varepsilon=\rho-\eta)$ 。

一方、点 $\mathrm{G}_{1}$ 回りの角度について次式の関係式を得 る。

$$
\begin{aligned}
& 360^{\circ}=\mu_{1}+90^{\circ}-\theta_{2}+\nu+90^{\circ} \text { より、 } \\
& \mu_{1}=180^{\circ}+\theta_{2}-\nu
\end{aligned}
$$

ここに $\triangle \mathrm{G}_{1} \mathrm{QA}$ において、次式の関係式を得る。

$$
\nu=90^{\circ}-\varepsilon
$$

式（7-11）を式（7-10）へ代入し、さらに ると、 $\mu_{1}$ が得られる。

$$
\begin{aligned}
\mu_{1} & =180^{\circ}+\theta_{2}-\left(90^{\circ}-\varepsilon\right)=90^{\circ}+\theta_{2}+\varepsilon \\
& =90^{\circ}+\theta_{2}+\rho-\eta
\end{aligned}
$$

そして $\triangle \mathrm{OG}_{3} \mathrm{G}_{1}$ において、次式により $\mathrm{m}_{1}$ が求めら れ $\theta_{1}$ が得られる。

$$
\begin{aligned}
& m_{1}^{2}=d_{2}^{2}+4 a^{2}-4 a d_{2} \cos \mu_{1}, \\
& \theta_{1}=\operatorname{Sin}^{-1}\left(\frac{2 a}{m_{1}} \sin \mu_{1}\right)
\end{aligned}
$$

(3) 方位角 $\theta_{3}$ の算出

図 4 の点A回りの角度について、次式の関係式を 得る。

$$
\gamma=180^{\circ}-\varphi-\rho
$$

また点 $\mathrm{G}_{2}$ 回りの角度について、次式の関係式を得 る。

$$
360^{\circ}=\mu_{3}+90^{\circ}-\theta_{2}+180^{\circ}-\gamma \text { より、 }
$$

$$
\mu_{3}=90^{\circ}+\theta_{2}+\gamma
$$

一方 $\triangle \mathrm{OG}_{2} \mathrm{G}_{4}$ において、次式により $\mathrm{m}_{3}$ が求められ $\theta_{3}$ が得られる。

$$
\begin{aligned}
& m_{3}{ }^{2}=d_{2}{ }^{2}+4 b^{2}-4 b d_{2} \cos \mu_{3}, \\
& \theta_{3}=\operatorname{Sin}^{-1}\left(\frac{2 b}{m_{3}} \sin \mu_{3}\right)
\end{aligned}
$$

同様にして、橋脚各部位の幾何学的衝突確率を算 定することがでさる。

\section{2 潮流による衝突確率}

\section{2 .1 計算手順}

機関および舵故障等した船舶が、潮流により漂流 して矩形橋脚へ衝突する確率の計算手順を困 5 に示 す。風による場合と同様に、海域のある場所におい て漂流事故を発生し、流れの向きに沿って漂流して 橋脚に衝突する場合を考える。

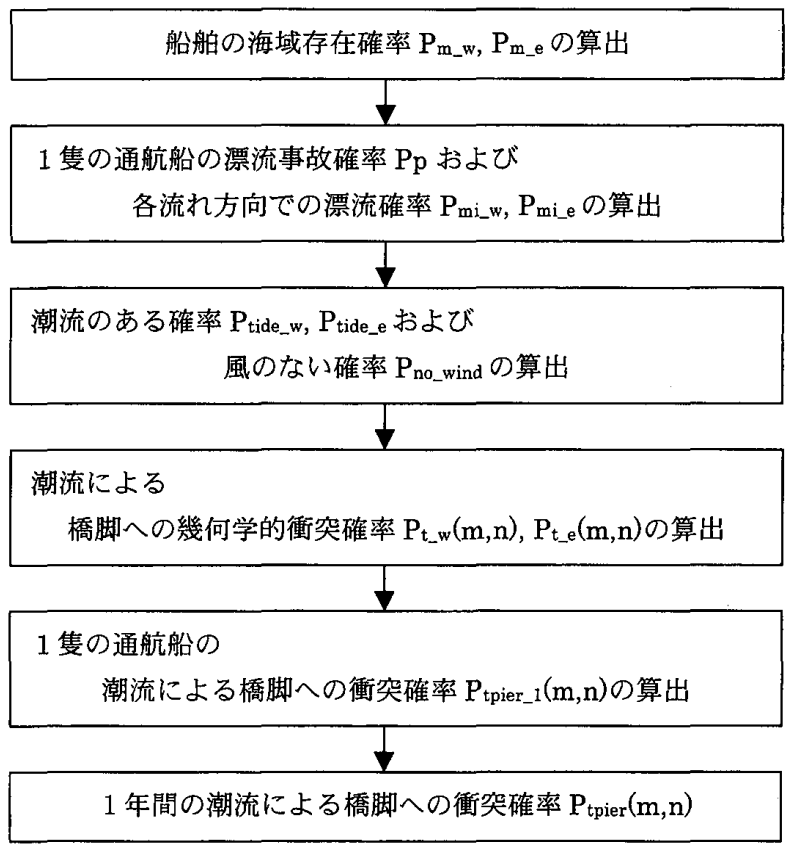

図 5 潮流による衝突確率の計算手順

（1）船舶の海域存在確率 $\mathrm{P}_{\mathrm{m}_{-} \mathrm{w}}$ および $\mathrm{P}_{\mathrm{m}_{-} \mathrm{e}}$

船舶通航害態調査等および海域の流況図を作成す ることにより、図 6 に示すような橋脚からみた各流 れ力向に存在する隻数を累計して存在隻数 $N_{-} w$ およ びN_eを算出することができる。そして式(8)のよう に潮流の流れ方向ごとに海域存在確率 $\left(\mathrm{P}_{\mathrm{m}_{-} \mathrm{w}}\right.$ および

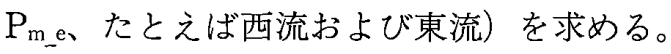

$$
P_{m_{-} w}=\frac{N_{-w}}{N_{T}}, \quad P_{m_{-} e}=\frac{N_{-e}}{N_{T}}
$$




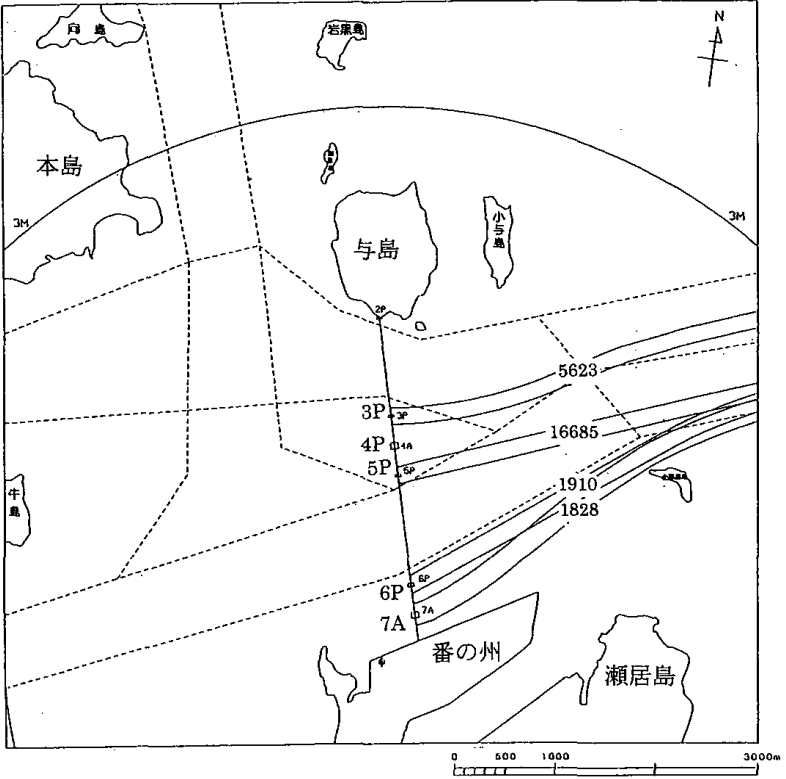

図 6 潮流域における船舶の海域存在隻数分布 (西流の場合)

（2）漂流事故確率 $\mathrm{P}_{\mathrm{p}}$ および各流れ方向での漂流確 率 $\mathrm{P}_{\text {mi_w、 }} \mathrm{P}_{\text {mie }}$

通航船の 1 隻が海域航行中に漂流する確率 $\mathrm{P}_{\mathrm{p}}$ は、 風による漂流事故の場合と同様に求める。すると 1 隻の通航船が海域航行中に各流れのあるときに漂流 する確率 $\mathrm{P}_{\mathrm{mi} \text { - }}$ および $\mathrm{P}_{\mathrm{mi} \_}$は以下のようになる。

$$
P_{m i_{-} w}=P_{p} \times P_{m_{-} w}, P_{m i_{-} e}=P_{p} \times P_{m_{-} e}
$$

（3）潮流のある確率 $\mathrm{P}_{\text {tide }}$ w、 $\mathrm{P}_{\text {tide_e }}$ および風のない確 率 $\mathrm{P}_{\text {no_wind }}$

当該海域における過去の潮流観測デー夕を統計処 理して、潮流の存在する確率を各流れ向きごとに求 める $\left(\mathrm{P}_{\text {tide_w、 }} \mathrm{P}_{\text {tide_e }}\right)$ 。またここでは潮流のみにより 船舶が漂流する場合を考えているため、海域が所定 の風速以下となる（風のない場合とみなす）確率 $\mathrm{P}_{\text {no_wind }}$ を合せて設定する。

（4） 1 隻の通航船が潮流により橋脚へ衝突する確率

$$
P_{\text {tpier_l }_{-}}(\mathrm{m}, \mathrm{n})
$$

以上より、1 隻の通航船が海域航行中に漂流して 橋脚 $\mathrm{m}$ の辺または頂点 $\mathrm{n}$ 一衝㚙する確率 $\mathrm{P}_{\mathrm{tpier}-1}$ $(\mathrm{m}, \mathrm{n})$ は式(10)のように算出される。

$$
\begin{aligned}
& P_{t p i e r_{-} I}(m, n)=P_{n o_{-} \text {wind }} \times\left(P_{m i_{-} w} \times P_{\text {tide } w} w\right. \\
& \left.\times P_{t_{-} w}(m, n)+P_{m i_{-} e} \times P_{\text {tide } e} \times P_{t_{-} e}(m, n)\right)
\end{aligned}
$$

ここに、 $\mathrm{P}_{\mathrm{t}_{-} \mathrm{w}}(\mathrm{m}, \mathrm{n}), \mathrm{P}_{\mathrm{t}_{-} \mathrm{e}}(\mathrm{m}, \mathrm{n})$ は潮流による漂流船 の橋脚 $m$ の辺または頂点 $\mathrm{n}$ への幾何学的衝突確率 である。

（5） 1 年間の潮流による橋脚への衝㚙確率 $\mathrm{P}_{\text {tpier }}$ $(\mathrm{m}, \mathrm{n})$
式(10)を用いて、 1 年間に橋㑢 $\mathrm{m}$ の辺または頂点 $\mathrm{n}$ へ衝突する確率 $\mathrm{P}_{\text {tpier }}(\mathrm{m}, \mathrm{n})$ は、式(11)のように算定さ れることになる。

$$
P_{\text {tpier }}(m, n)=P_{\text {tpier__ }}(m, n) \times N_{s_{-} \text {year }}
$$

2.2.2 潮流による幾何学的衝突確率の計算 $\left(\mathrm{P}_{\mathrm{t}_{-} \mathrm{w}}\right.$ $\left.(\mathrm{m}, \mathrm{n}), \mathrm{P}_{\mathrm{t}-\mathrm{e}}(\mathrm{m}, \mathrm{n})\right)$

潮流による橋脚 $\mathrm{m}$ の辺または頂点 $\mathrm{n}$ への漂流船 の幾何学的衝突確率 $\left(\mathrm{P}_{\mathrm{t} w}(\mathrm{~m}, \mathrm{n}), \mathrm{P}_{\mathrm{t} e}(\mathrm{~m}, \mathrm{n})\right)$ は各 流れ向きごとに次のように求める。

漂流船は流れに対して船首尾線を直角にして漂流 するものと仮定する。すると図 6 に示すように、対 象海域中に各橋脚に衝突する海域を各流れ向きごと に設定することができ、漂流船の橋脚に対する衝突 角度が決まることになる。困 7 に橋脚と漂流船の位 犆関係の詳細困を示す。このとき漂流船の橋脚に衝 突する総投影距離を $\mathrm{B}$ するとき、この距離 $\mathrm{B}$ に対す る各部位の投影距離の割合から衝突確率を求める。 なお各投影距離は、橋脚と漂流船の衝突角度、また 漂流船舶の船長および橋脚の形状により以下のよう に幾何学的に算出することができる。

$$
\begin{aligned}
& x_{t}=2 a \sin \alpha_{t}, \mathrm{y}_{t}=2 b \cos \alpha_{t}, B=x_{t}+2 s+y_{t} \text { より、 } \\
& P_{t_{-} w}(m, 1)=\frac{x_{t}}{B}, P_{t_{-} w}(m, 2)=\frac{2 s}{B}, \\
& P_{t_{-} w}(m, 3)=\frac{y_{t}}{B}
\end{aligned}
$$

ここに、 $\alpha_{\mathrm{t}}$ : 橋脚に対子る潮流方位角、 $\mathrm{x}_{\mathrm{t}}$ : $\mathrm{P} 1$ に対 する投影距離、 $\mathrm{y}_{\mathrm{t}}$ : P3に対する投影距離、 $\mathrm{B}$ : 橋脚に 船舶が衝突する総投影距離である。

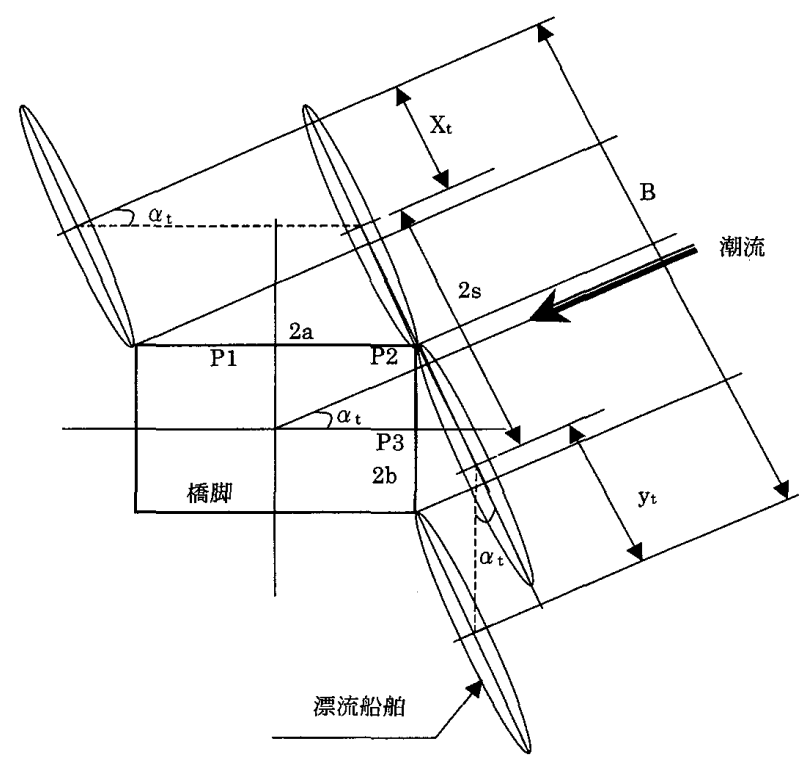

図 7 潮流による漂流船と橋脚との位置関係 (潮流による幾何学的衝突確率) 
同様にして、橋脚各部位の幾何学的衝突確率を算 出することができる。

\section{3. 南北備讃瀬戸大橋についての適用事例}

上述の風および潮流により生じる矩形橋脚への漂 流船の衝突確率計算手法を南北備讃瀬戸大橋入適用 してみる。

\section{1 船舶の衝突シナリオ}

南北備讃瀬戸大橋における船舶の衝突シナリオの 内、機関および舵故障等により船舶が風または潮流 により漂流して矩形橋脚へ衝突するケースを以下に 列挙する。

橋脚 $3 \mathrm{P}$ : (1)北航路西航船が、舵・機関の故障等によ ク漂流し橋脚に衝突する可能性があ る。

(2)水島航路通航船が、舵・機関の故障等に より漂流し橋脚に衝突する可能性があ る。

橋脚 $5 \mathrm{P}$ : (1)南航路東航船が、舵・機関の故障等によ り漂流し橋脚に衝突する可能性があ る。

(2)南航路から水島航路、水島航路から南 航路へ出入りする船が、舵・機関の故障 等により漂流し橋脚に衝突する可能性 がある。

橋脚 $6 \mathrm{P}$ : (1)南航路東航船が、舵・機関の故障等によ り漂流し橋脚に衝突する可能性があ る。

(2)水島航路から南航路入入る船が、舵・機 関の故障等により漂流し橋脚に衝突す る可能性がある。

(3)航路外を航行する小型船が、舵・機関の 故障等により漂流し橋脚に衝突する可 能性がある。

橋脚 $7 \mathrm{~A}$ ：橋脚 $6 \mathrm{P}$ と同じことが考えられる。

\section{2 矩形橋脚への衝突確率計算結果}

3.2 .1 風による衝突確率計算について

(1) 船舶の海域存在確率 $\mathrm{P}_{\mathrm{m}}(\mathrm{d}, \phi)$

平成11年 5 月 18 日 5 月 21 日の 3 日間（72時間連 続）に船舶通航実態調査を行った。図 8 に調查地点 と各航路の位置関係および国 9 に調査結果内の一部 の航跡図を示す。

まず船舶通航実態調查結果から、船舶の海域にお ける存在隻数を橋脚ごとにまとめた。一例として 3 Pについての海域存在隻数を四10に示す。この海域 存在隻数の累計に際しては、海域の水深困や島など の障害物と橋脚との遮蔽関係を考慮して、海域メッ

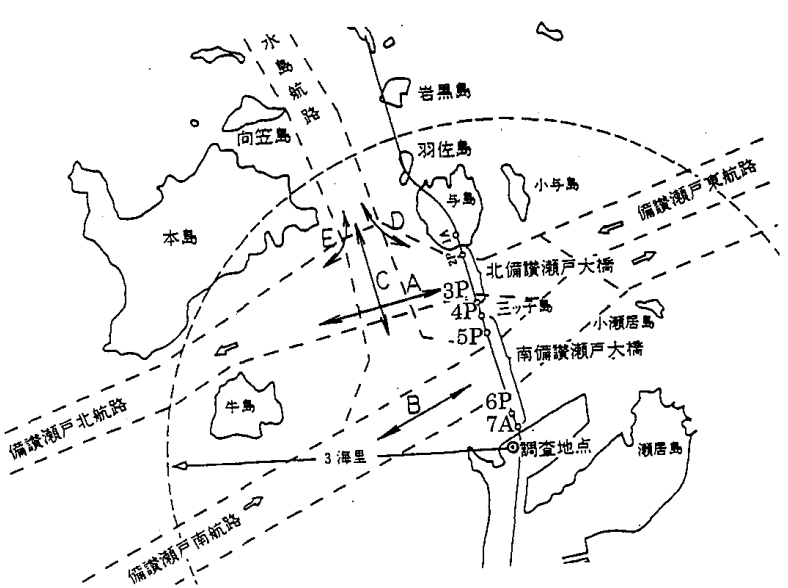

困 8 船舶通航実態調査の調查地点と各航路の位置 関係

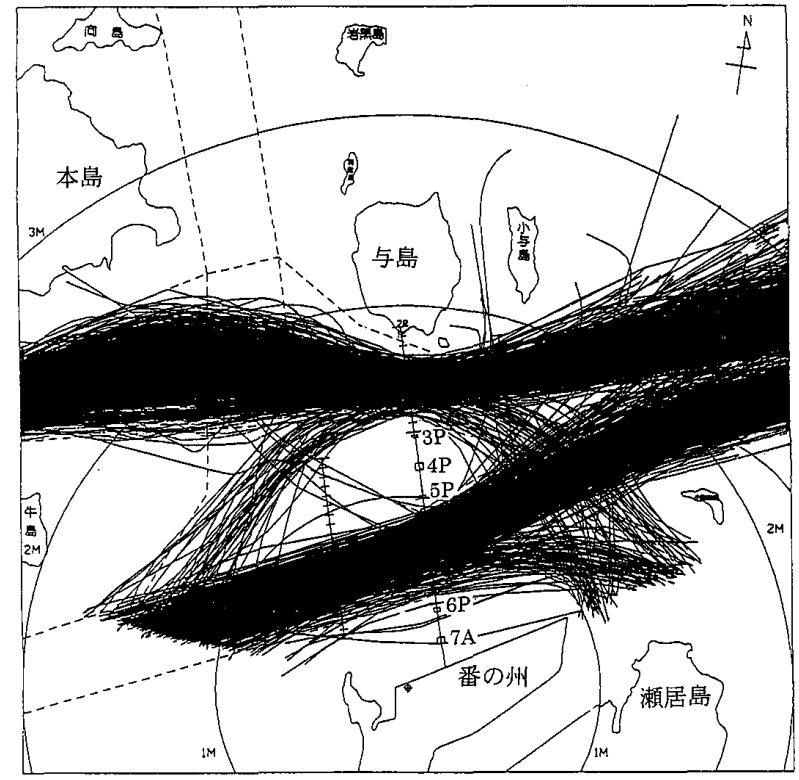

図 9 船舶通航実態調查による航跡困 (航路直航船通航状沿)

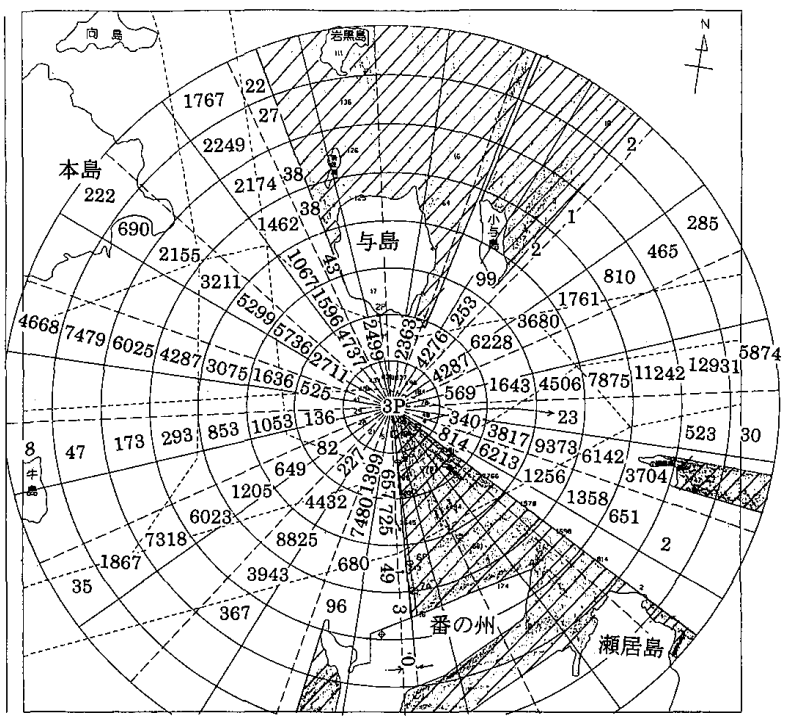

困10 船船の海域存在隻数分布 (橋脚 $3 \mathrm{P}$ 、風による衝突) 
表 1 存在隻数・海域存在確率 $\mathrm{P}_{\mathrm{m}} \cdot$ 漂流確率 $\mathrm{P}_{\mathrm{mi}}$ およU゙風の吹く確率: $\mathrm{P}_{\mathrm{w}}$

(橋脚 $3 \mathrm{P}$ 、距離 $\mathrm{d}=2250 \mathrm{~m}$ )

\begin{tabular}{|r|c|c|c|c|}
\hline 方位 $\phi(\mathrm{deg})$ & 船隻数 & $\begin{array}{c}\text { 存在確率 } \\
\mathrm{P}_{\mathrm{m}}\end{array}$ & $\begin{array}{c}\text { 漂流確率 } \\
\mathrm{P}_{\mathrm{mi}}\end{array}$ & $\begin{array}{c}\text { 風確率 } \\
\mathrm{P}_{\mathrm{w}}\end{array}$ \\
\hline 0 & 0 & 0 & 0 & 0.010 \\
\hline 22.5 & 2 & $8.40 \mathrm{E}-06$ & $5.20 \mathrm{E}-11$ & 0.019 \\
\hline 45 & 1761 & $7.39 \mathrm{E}-03$ & $4.58 \mathrm{E}-08$ & 0.010 \\
\hline 67.5 & 7875 & $3.31 \mathrm{E}-02$ & $2.05 \mathrm{E}-07$ & 0.017 \\
\hline 90 & 6142 & $2.58 \mathrm{E}-02$ & $1.60 \mathrm{E}-07$ & 0.004 \\
\hline 112.5 & 1358 & $5.70 \mathrm{E}-03$ & $3.53 \mathrm{E}-08$ & 0.001 \\
\hline 135 & 0 & 0 & 0 & 0.001 \\
\hline 157.5 & 3 & $1.26 \mathrm{E}-05$ & $7.79 \mathrm{E}-11$ & 0.000 \\
\hline 180 & 96 & $4.03 \mathrm{E}-04$ & $2.49 \mathrm{E}-09$ & 0.000 \\
\hline 202.5 & 3943 & $1.66 \mathrm{E}-02$ & $1.02 \mathrm{E}-07$ & 0.000 \\
\hline 225 & 6023 & $2.53 \mathrm{E}-02$ & $1.56 \mathrm{E}-07$ & 0.002 \\
\hline 247.5 & 293 & $1.23 \mathrm{E}-03$ & $7.61 \mathrm{E}-09$ & 0.010 \\
\hline 270 & 4287 & $1.80 \mathrm{E}-02$ & $1.11 \mathrm{E}-07$ & 0.042 \\
\hline 292.5 & 3211 & $1.35 \mathrm{E}-02$ & $8.34 \mathrm{E}-08$ & 0.031 \\
\hline 315 & 1462 & $6.14 \mathrm{E}-03$ & $3.80 \mathrm{E}-08$ & 0.038 \\
\hline 337.5 & 38 & $1.60 \mathrm{E}-04$ & $9.87 \mathrm{E}-10$ & 0.014 \\
\hline
\end{tabular}

（㫻考）衝突事故確率： $\mathrm{P}_{\mathrm{p}}=6.19 \mathrm{E}-06$

シュごとに実態調查から算定された存在隻数に対し て修正を施している。な㧍メッシュ分割は、方位分 割については風方位に合せて16分割とし、距離につ

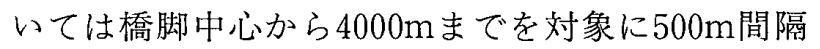
で分割した。したがって海域分割個数は $\mathrm{ND}=16 \times$ 8=128ケとなる。海域メッシュ分割は、対象船船の 大きさ (船長) や必要とされる計算精度に応じて調 整される。また対象海域の存在隻数の総数は $\mathrm{N}_{\mathrm{T}}=$ 238,225隻であった。一例として表 1 に、橋脚 $3 \mathrm{P}$ に

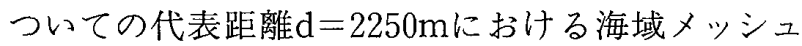
での存在隻数扔よび海域存在確率 $\mathrm{P}_{\mathrm{m}}$ を示す。

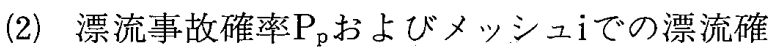
率 $\mathrm{P}_{\mathrm{mi}}(\mathrm{d}, \phi)$

昭和 55 年一昭和 62 年の 8 年間に発生した機関およ び舵故障による漂流事故は10件であった。一方 3 日 間の実態調查から通航隻数は、備讃瀬戸北航路通航 隻数 $\mathrm{n}_{1}=750$ 隻、南航路通航隻数 $\mathrm{n}_{2}=750$ 隻扝よび水 島航路通航隻数 $n_{3}=160$ 隻であった。以上より式(2)を 用いて通航船の 1 隻が海域航行中に漂流する確率 $\mathrm{P}_{\mathrm{p}}$ は式(13)のように求められ、1隻の通航船が海域航 行中にメッシュiの位置で機関故障等により漂流す る確率 $\mathrm{P}_{\mathrm{m} 1}(\mathrm{~d}, \phi)$ も式(3)を用いて算出される。同様に 表 1 に、橋脚 $3 \mathrm{P}$ についての代表距離 $\mathrm{d}=2250 \mathrm{~m}$ にお ける漂流確率 $P_{\mathrm{m} 1}$ を示す。

$$
\begin{aligned}
& P_{p}=\frac{N_{a}}{N_{s}}=6.19 \times 10^{-6}, \mathrm{Na}=10, \\
& \mathrm{Ns}=\left(\mathrm{n}_{1}+\mathrm{n}_{2}+\mathrm{n}_{3}\right) \times 365 / 3 \times 8
\end{aligned}
$$

(3) 風の吹く確率 $\mathrm{P}_{w}(\phi)$ 抢よび潮流のない確率 $P_{\text {no tide }}$

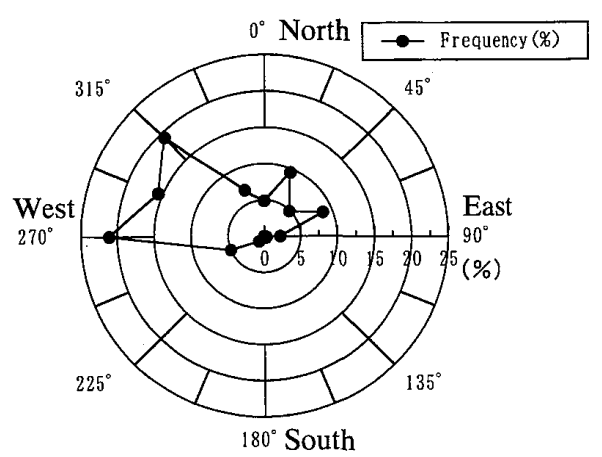

図11風速 $7 \mathrm{~m} / \mathrm{s}$ 以上の風向き別出現頻度

ここでは風による漂流を考慮する風速は $7 \mathrm{~m} / \mathrm{s}$ 以 上と設定した。図11に示すように、風速 $7 \mathrm{~m} / \mathrm{s}$ 以上の 風向き別出現頻度を昭和 54 年 〜昭和58年の 5 年間の 観測データからまとめた。また全観測中における風 速 $7 \mathrm{~m} / \mathrm{s}$ 以上の風の吹く割合が $\mathrm{P}_{\mathrm{w} 7}=0.199$ であった ことより、風の吹く確率 $\mathrm{P}_{\mathrm{w}}$ を表 1 のように算出し た。また潮流のない確率 $\mathrm{P}_{\mathrm{no} \text { _tide }}$ は 1 日24時間の内、東 流・西流および憩流時の 3 種類があることから、 $\mathrm{P}_{\text {no_tide }}=8 / 24=1 / 3$ と設定した。

（4）風による幾何学的衝突確率 $\mathrm{P}_{\mathrm{wpier}}(\mathrm{m}, \mathrm{n})$

幾何学的衝突確率を算出するに際しての設定条件 を表 2 に示す。表 3 に一例として橋脚 3 Pについて の代表距離 $\mathrm{d}=2250 \mathrm{~m}$ に扔ける橋脚各部位をみる角 度の計算結果を示す。同様に橋脚からの距離および

\begin{tabular}{|c|c|c|c|c|}
\hline \multirow{2}{*}{ 橋 脚 } & \multirow{2}{*}{$\begin{array}{c}\text { 船長 }(m) \\
L=2 s\end{array}$} & \multirow{2}{*}{$\begin{array}{l}\text { 橋脚方位 } \\
\phi_{\mathrm{p}}(\mathrm{deg})\end{array}$} & \multicolumn{2}{|c|}{ 橋脚形状 $(\mathrm{m})$} \\
\hline & & & $2 a$ & $2 \mathrm{~b}$ \\
\hline $3 \mathrm{P}$ & \multirow{4}{*}{70} & \multirow{4}{*}{344} & 57 & 23 \\
\hline $5 \mathrm{P}$ & & & 59 & 27 \\
\hline $6 \mathrm{P}$ & & & 59 & 38 \\
\hline $7 \mathrm{~A}$ & & & 59 & 75 \\
\hline
\end{tabular}

表 2 幾何学的衝突確率計算における設定条件

表 3 風による衝突における橋脚各部位をみる角度 (deg)（橋脚 $3 \mathrm{P}$ 、距離 $\mathrm{d}=2250 \mathrm{~m}$ )

\begin{tabular}{|r|c|c|c|c|c|c|c|c|}
\hline 方位 $\phi$ (deg) & P1 & P2 & P3 & P4 & P5 & P6 & P7 & P8 \\
\hline 0 & 1.39 & 1.80 & 0.15 & 0 & 0 & 0 & 0 & 0 \\
\hline 22.5 & 1.12 & 1.80 & 0.36 & 0 & 0 & 0 & 0 & 0 \\
\hline 45 & 0.68 & 1.81 & 0.51 & 0 & 0 & 0 & 0 & 0 \\
\hline 67.5 & 0.13 & 1.81 & 0.59 & 0 & 0 & 0 & 0 & 0 \\
\hline 90 & 0 & 0 & 0.57 & 1.81 & 0.37 & 0 & 0 & 0 \\
\hline 112.5 & 0 & 0 & 0.45 & 1.81 & 0.88 & 0 & 0 & 0 \\
\hline 135 & 0 & 0 & 0.27 & 1.80 & 1.26 & 0 & 0 & 0 \\
\hline 157.5 & 0 & 0 & 0.05 & 1.79 & 1.45 & 0 & 0 & 0 \\
\hline 180 & 0 & 0 & 0 & 0 & 1.39 & 1.80 & 0.15 & 0 \\
\hline 202.5 & 0 & 0 & 0 & 0 & 1.12 & 1.80 & 0.36 & 0 \\
\hline 225 & 0 & 0 & 0 & 0 & 0.68 & 1.81 & 0.51 & 0 \\
\hline 247.5 & 0 & 0 & 0 & 0 & 0.13 & 1.81 & 0.59 & 0 \\
\hline 270 & 0.37 & 0 & 0 & 0 & 0 & 0 & 0.57 & 1.81 \\
\hline 292.5 & 0.88 & 0 & 0 & 0 & 0 & 0 & 0.45 & 1.81 \\
\hline 315 & 1.26 & 0 & 0 & 0 & 0 & 0 & 0.27 & 1.80 \\
\hline 337.5 & 1.45 & 0 & 0 & 0 & 0 & 0 & 0.05 & 1.79 \\
\hline
\end{tabular}

(菕考) メッシュの方位分割幅 : $\theta_{0}=22,5 \mathrm{deg}$ 
他の橋脚についての各部位をみる角度を求め、式(6) により幾何学的衝突確率を算定した。なお方位分割 幅は $\theta_{0}=22.5 \mathrm{deg}$ とした。

3.2 .2 潮流による衝突確率計算について

（1）船舶の海域存在確率 $\mathrm{P}_{\mathrm{m}_{-} \mathrm{w}}$ および $\mathrm{P}_{\mathrm{m}_{-} \mathrm{e}}$

西流および東流最強時の流況困を作成して、橋脚 から潮流に沿って対象船舶の船長の 2 倍の海域幅に おける存在隻数を抽出した。前述の図 6 に、西流時 の存在隻数分布を一例として示す。また表 4 に、潮 流による衝突確率計算に際して用いた設定条件およ び船舶の海域存在確率 $\mathrm{P}_{\mathrm{m}_{-} \mathrm{w}}$ および $\mathrm{P}_{\mathrm{m}_{-} \mathrm{e}}$ をまめる。

表 4 潮流による衝突確率計算

\begin{tabular}{|c|c|c|c|c|c|c|}
\hline \multirow[b]{2}{*}{ 撟 脚 } & \multicolumn{3}{|c|}{ 防 流 } & \multicolumn{3}{|c|}{ 東 流 } \\
\hline & N_w & $\begin{array}{c}\phi_{w} \\
(\mathrm{deg})\end{array}$ & $P_{m i_{-} w}$ & $\mathrm{~N}_{-} \mathrm{e}$ & $\begin{array}{c}\phi_{\mathrm{o}} \\
(\mathrm{deg})\end{array}$ & $\mathrm{P}_{\text {si__e }}$ \\
\hline $3 \mathrm{P}$ & 5623 & 78 & $1.46 \mathrm{E} \cdot 07$ & 784 & 242 & $2.04 \mathrm{E}-08$ \\
\hline $5 \mathrm{P}$ & 16685 & 67 & $4.33 \mathrm{E}-07$ & 954 & 254 & $2.48 \mathrm{E}-08$ \\
\hline $6 \mathrm{P}$ & 1910 & 52 & $4,96 \mathrm{E} \cdot 08$ & 160 & 254 & $4.16 \mathrm{E} \cdot 09$ \\
\hline $7 \mathrm{~A}$ & 1828 & 57 & $4.75 \mathrm{E} \cdot 08$ & 161 & 259 & $4.18 \mathrm{E}-09$ \\
\hline
\end{tabular}

方位 $\phi_{\mathrm{w}}$ および $\phi_{\mathrm{e}}$ は西流および東流の橋脚に対する 入射方位角度である。

(2) 漂流事故確率 $\mathrm{P}_{\mathrm{p}}$ およU゙漂流確率 $\mathrm{P}_{\mathrm{mi}}$ w、 $\mathrm{P}_{\mathrm{mi}} \mathrm{e}$

漂流事故確率 $\mathrm{P}_{\mathrm{p}}$ は風による衝突で求めた值を流 用した。

（3）潮流のある確率 $\mathrm{P}_{\text {tide_w、 }} \mathrm{P}_{\text {tide_e }}$ および風のない 確率P $\mathrm{P}_{\text {no_wind }}$

潮流のない確率 $\mathrm{P}_{\text {no_tide }}$ 前述のように $\mathrm{P}_{\text {no_tide }}=$ $8 / 24=1 / 3$ と設定していることおよび西流および東 流の 2 種類の潮流があることから、西流および東流 のある確率はそれぞれ $\mathrm{P}_{\text {tide_w }}=2 / 3 \times 1 / 2 、 \mathrm{P}_{\text {tide_e }}=2 /$ $3 \times 1 / 2$ と設定した。また風のない確率 $\mathrm{P}_{\mathrm{no}}$ wind は、風 速 $7 \mathrm{~m} / \mathrm{s}$ 以上の風の吹く割合を $\mathrm{P}_{\mathrm{w} 7}=0.199$ と設定し ていることから $\mathrm{P}_{\text {no wind }}=0.801$ とした。

（4）潮流による幾何学的衝突確率の計算 $\left(\mathrm{P}_{\mathrm{t}-\mathrm{w}}\right.$ $\left.(\mathrm{m}, \mathrm{n}), \mathrm{P}_{\mathrm{t} e}(\mathrm{~m}, \mathrm{n})\right)$

表 2 に示した対象船舶と各橋脚の形状および表 4 の橋脚に対する潮流の入射方位角度 $\phi_{\mathrm{w}}$ と $\phi_{\mathrm{e}}$ を用い て、式(12)により潮流による幾何学的衝突確率を算定 した。

\section{2 .3 衝突確率計算結果のまとめ}

3 日間の実態調查での通航隻数から、 1 年間に当 該海域を航行する総隻数は $\mathrm{N}_{\text {s_year }}=\left(\mathrm{n}_{1}+\mathrm{n}_{2}+\mathrm{n}_{3}\right) \times$ 365/3=201,967隻と算定した。そして式(5)および式 (11)を用いて、1年間に風抢よび潮流により生じる橋 脚への衝突確率を計算した。表 5 に衝突形態、各橋 脚および各部位ごとに 1 年間の衝突回数をまとめ た。また表 6 には、その合計值のみにつき逆数をとっ
表 5 衝突形態別の衝笑確率計算結果 ( 1 年間の衝突回数)

\begin{tabular}{|c|c|c|c|c|c|c|c|c|c|}
\hline 㨎脚 & 形態 & P1 & P2 & P3 & P4 & P5 & P6 & P7 & P8 \\
\hline \multirow[t]{3}{*}{$3 P$} & 風 & $2.94 \mathrm{E} \cdot 04$ & $2.18 \mathrm{E} \cdot 04$ & $6.03 \mathrm{E}-05$ & $1.99 \mathrm{E} \cdot 05$ & $7.64 \mathrm{E} \cdot 06$ & 1.22E- 05 & $1.07 \mathrm{E} \cdot 04$ & $4.83 \mathrm{E} \cdot 04$ \\
\hline & 瑯流 & 0 & 0 & $1.87 \mathrm{E} \cdot 03$ & $5.69 \mathrm{E}-03$ & $4.48 \mathrm{E} \cdot 04$ & $7.37 \mathrm{E}-04$ & $2.37 \mathrm{E} \cdot 04$ & 0 \\
\hline & 令部 & $2.94 \mathrm{E}-04$ & $2.18 \mathrm{E} \cdot 04$ & $1.93 \mathrm{E} \cdot 03$ & $5.71 \mathrm{E} \cdot 03$ & $4.56 \mathrm{E} \cdot 04$ & $7.49 \mathrm{E}-04$ & $3.44 \mathrm{E} \cdot 04$ & $4.83 \mathrm{E}-04$ \\
\hline \multirow[t]{3}{*}{$5 P$} & 風 & $2.49 \mathrm{E}-04$ & $2.32 \mathrm{E} \cdot 04$ & $8.10 \mathrm{E} \cdot 05$ & $2.43 \mathrm{E}-05$ & $1.19 \mathrm{E} \cdot 05$ & $2.74 \mathrm{E}-05$ & $8.80 \mathrm{E} \cdot 05$ & $3.23 \mathrm{E} \cdot 04$ \\
\hline & 潮流 & $1.62 \mathrm{E} \cdot 03$ & $1.57 \mathrm{E} \cdot 02$ & $6.03 \mathrm{E} \cdot 03$ & 0 & 0 & 0 & $1.34 \mathrm{E} \cdot 03$ & 0 \\
\hline & 合計 & $1.87 \mathrm{E} \cdot 03$ & $1.60 \mathrm{E} \cdot 02$ & $6.11 \mathrm{E} \cdot 03$ & $2.43 \mathrm{E} \cdot 05$ & $1.19 \mathrm{E} \cdot 05$ & $2.74 \mathrm{E}-05$ & $1.43 \mathrm{E} \cdot 03$ & $3.23 E \cdot 04$ \\
\hline \multirow[t]{3}{*}{$6 \mathrm{P}$} & 風 & $4.35 \mathrm{E} \cdot 04$ & $2.48 \mathrm{E} \cdot 04$ & $7.98 \mathrm{E} \cdot 05$ & $3.54 \mathrm{E}-07$ & $7.77 \mathrm{E} \cdot 07$ & $1.03 \mathrm{E}-05$ & $2.09 \mathrm{E} \cdot 04$ & $5.96 \mathrm{E}-04$ \\
\hline & 湖流 & $4.65 \mathrm{E} \cdot 04$ & $1,47 \mathrm{E} \cdot 03$ & $7.41 \mathrm{E}-04$ & 0 & 0 & 0 & $2.24 \mathrm{E} \cdot 04$ & 0 \\
\hline & 命竐 & $8.99 \mathrm{E}-04$ & $1,72 \mathrm{E} \cdot 03$ & $8.20 \mathrm{E} \cdot 04$ & $3.54 \mathrm{E} \cdot 07$ & $7.77 \mathrm{E} \cdot 07$ & $1.03 \mathrm{E} \cdot 05$ & $4.33 \mathrm{E} \cdot 04$ & $5.96 \mathrm{E} \cdot 04$ \\
\hline \multirow[t]{3}{*}{$7 \mathrm{~A}$} & 䖝 & $3.69 \mathrm{E} \cdot 04$ & $2.02 \mathrm{E}-04$ & $1.21 E \cdot 04$ & $1.99 \mathrm{E} \cdot 08$ & $1.16 \mathrm{E} \cdot 08$ & $4.16 \mathrm{E} \cdot 07$ & $3.30 \mathrm{E} \cdot 04$ & $4.83 \mathrm{E} \cdot 04$ \\
\hline & 瀮流 & $2.86 \mathrm{E} \cdot 04$ & $1.13 \mathrm{E} \cdot 03$ & $1.16 \mathrm{E} \cdot 03$ & 0 & 0 & 0 & $1.13 \mathrm{E} \cdot 04$ & $1.05 \mathrm{E} \cdot 04$ \\
\hline & 合部 & $6.54 \mathrm{E} \cdot 04$ & $1.33 \mathrm{E} \cdot 03$ & $1.28 \mathrm{E} \cdot 03$ & $1.99 \mathrm{E}-08$ & $1.16 \mathrm{E} \cdot 08$ & $4.16 \mathrm{E} \cdot 07$ & $4.43 \mathrm{E} \cdot 04$ & $5.89 \mathrm{E}-04$ \\
\hline
\end{tabular}

表 6 衝突確率計算結果（衝突発生年数）

\begin{tabular}{|c|c|c|c|c|c|c|c|c|}
\hline 倸脚 & $\mathrm{P} 1$ & $\mathrm{P} 2$ & $\mathrm{P} 3$ & $\mathrm{P} 4$ & $\mathrm{P} 5$ & $\mathrm{P} 6$ & $\mathrm{P} 7$ & $\mathrm{P} 8$ \\
\hline $3 \mathrm{P}$ & $3.40 \mathrm{E}+03$ & $4.58 \mathrm{E}+03$ & $5.19 \mathrm{E}+02$ & $1.7 \mathrm{E}+02$ & $2.20 \mathrm{E}+03$ & $1.34 \mathrm{E}+03$ & $2.91 \mathrm{E}+03$ & $2.07 \mathrm{E}+03$ \\
\hline $5 \mathrm{P}$ & $5.36 \mathrm{E}+02$ & $6.26 \mathrm{E}+01$ & $1.64 \mathrm{E}+02$ & $4.12 \mathrm{E}+04$ & $8.40 \mathrm{E}+04$ & $3.65 \mathrm{E}+04$ & $7.02 \mathrm{E}+02$ & $3.09 \mathrm{E}+03$ \\
\hline $6 \mathrm{P}$ & $1.11 \mathrm{E}+03$ & $5.82 \mathrm{E}+02$ & $1.22 \mathrm{E}+03$ & $2.83 \mathrm{E}+06$ & $1.29 \mathrm{E}+06$ & $9.73 \mathrm{E}+04$ & $2.31 \mathrm{E}+03$ & $1.68 \mathrm{E}+03$ \\
\hline $7 \mathrm{~A}$ & $1.53 \mathrm{E}+03$ & $7.52 \mathrm{E}+02$ & $7.84 \mathrm{E}+02$ & $5.02 \mathrm{E}+07$ & $8.62 \mathrm{E}+07$ & $2.41 \mathrm{E}+06$ & $2.26 \mathrm{E}+03$ & $1.70 \mathrm{E}+03$ \\
\hline
\end{tabular}

て、橋脚各部位に衝突する年数を算出した。

これをみると、橋脚 $5 \mathrm{P}$ 部位P2の位置が特に高 い衝突確率を示し、約63年に 1 回の衝突事故が発生 する結果を得た。部位P2の位置は北東コー十部にあ ク、風による衝笑確率は低いが、潮流（西流時）時 の流域における船舶の存在隻数が多かったことか ら、衝突確率が高い值となったものと考えられる。

\section{4. 結語}

以上、風および潮流により生じる矩形橋脚への漂 流船の衝突確率計算手法を提案すると共に、当該計 算手法の南北備讃瀬戸大橋への適用事例を紹介し た。本研究で得られた知見が船舶の安全な運航に寄 与することを願うと共に、南北備讃瀬戸大橋の運用 に役立つことを祈念するものである。また本研究の 実施に当たっては、様々な方々にご支援とご教授を 賜った。関係者の皆様に媣く感謝します。

\section{参 考 文 献}

（1）岩井 聡・庄司邦昭 - 亀田久治：船舶の衝突に 対する緩衝施設に関する研究（その2）－漂流 船の衝突挙動について一，東京商船大学研究報 告 (自然科学)，第33号，pp.25-42，1982.

（2）本州四国連絡橋公団 - (社)日本海難防止協会：本 州四国連絡橋航行安全調查報告書, 航行安全調 査その $1 ， 1991$.

（3）本州四国連絡橋公団 - 社)日本海難防止協会：本 州四国連絡橋航行安全調查報告書, 航行安全調 査その $1,1996$. 
(4) O. D. Larsen : Ship Collision Risk Assessment for Bridges, IABSE Reports, Volume-Band 41, pp.113-128, 1983.

（5）本州四国連絡橋公団・社)日.本海難防止協会：南 北備讃瀬戸大橋の緩衝工に関する調查検討報告 書, pp.70-76, 1999.

\section{質 疑 応 答}

定兼廣行(神戸商船大学)：実際には、船体は船型等 により、風に対して直角には漂流しませんが修正
することは可能ですか。また潮流についても、橋 脚周りなど複雑な流況を考慮できるように修正す ることはできますか。

柇原繁樹：今回提案した幾何学的衝突確率計算等の 計算手法をそのまま使用することはできないかも しれませんが、風による漂流姿勢、また複雑な潮 流下での船体の漂流姿勢を設定することで、同様 に計算式等を構築または修正することは可能と考 えています。 